\title{
Symbolic Interactionism in Poland. Inspirations and Development
}

\author{
Krzysztof T. Konecki \\ University of Lodz, Poland
}

\author{
Anna Kacperczyk \\ University of Lodz, Poland
}

DOI: http://dx.doi.org/10.18778/1733-8077.16.4.02

\section{Keywords:}

Symbolic Interactionism; History of Sociology; Polish Researchers; Grounded Theory; Polish Sociology; Qualitative Methods; Qualitative Sociology; Sociological Theory

\begin{abstract}
In the paper, we present the development of symbolic interactionism (SI) in Poland by tracing and discussing its beginnings, as well as the influence the Chicago School had on the reception of SI in Polish sociology. Furthermore, we differentiate between two trends in the development of SI in Poland. One is connected with the early theoretical elaborations of the SI orientation and translations of classical books representing this perspective; another is linked with empirical work underpinned by SI concepts and the grounded theory approach in empirical research and data analysis. Stressing the importance of translations of classical texts of SI in its reception in Poland, we emphasize the role of field research and applications of SI concepts in sociological investigations that we shortly characterize.
\end{abstract}

Krzysztof T. Konecki is a Full Professor at the Faculty of Economics and Sociology, University of Lodz, Poland. He is the head of the Sociology of Organization and Management Department. His interests lie in qualitative sociology, symbolic interactionism, grounded theory, the methodology of social sciences, visual sociology, communication and intercultural management, organizational culture and management, and contemplative studies. He is the editor-in-chief of the Qualitative Sociology Review, and he holds the position of the President of the Polish Sociological Association.

email address: krzysztof.konecki@uni.lodz.pl

Anna Kacperczyk is an Associate Professor of sociology at the University of Lodz, Poland. Substantive areas of her research included palliative and hospice care in Poland (2006), the sustainable development of an Amazonian village (2013), the social world of climbing (2016), and trash (in press). She is interested in the theory of social worlds, the methodology of social research, especially the issue of the position and role of the researcher in the investigation process. In her field research, she refers to the theoretical framework of symbolic interactionism, using ethnography, autoethnography, and methodology of grounded theory. She is a chairperson of the Section of Qualitative Sociology and Symbolic Interactionism of the Polish Sociological Association and a member of the board of European Society for the Study of Symbolic Interaction. She serves as an associate editor and cover designer of the Qualitative Sociology Review.

email address: anna.kacperczyk@uni.lodz.pl 


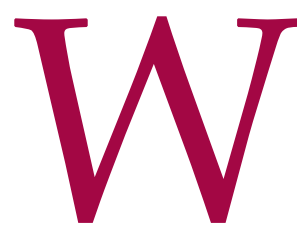

hile attempting to write about the development of symbolic interactionism (SI) in Poland, one must indicate the main inspirations and works that helped popularize this theoretical orientation, and that used the methods and concepts of SI in empirical research. ${ }^{1}$ We write about the works that directly refer to SI as a perspective used in sociological theorizing, as well as field studies. We do not widely discuss the works that mention the SI perspective marginally, with no analysis of its fundamental assumptions or application of its concepts in empirical research, nor which use them only as an "adornment" by mere reference to this orientation. Our emphasis is on the works that combined empirical research with the perspective of SI.

One can argue that the development of qualitative sociology in Poland was directly connected with the theoretical grounding of the qualitative sociological research in the Chicago School and SI (Hałas 1987; 1994; Wyka 1988; Konecki, Kacperczyk, and Marciniak 2005). Even if this development is not referred to directly, it is included in the general perspective of the qualitative studies-in the concepts of identity, self, the definition of the self, the transformation of self/ identity, the definition of the situation, social organization, or social worlds. These concepts are the effect of the influences of SI but also derive from the Chicago School, with its works that embraced the personal, subjective view of reality, the social organization, human practices in everyday life, and work processes with particular emphasis on the field studies, fieldwork, and qualitative methods of research, including personal documents (Schatzman and Strauss 1973; Strauss 1987; 1993).

\footnotetext{
${ }^{1}$ This article is based on the presentation delivered by the authors at the $8^{\text {th }}$ Conference of the European Society for the Study of Symbolic Interaction, Studying Everyday Life: Generic Dimensions of Interactionist Inquiry, held in Lodz, Poland, July 04-08, 2017.
}

\section{The Beginnings-Theoretical and Methodological Orientation}

It is assumed that the works of scholars at the University of Chicago had an impact on the development of SI and qualitative sociology. Robert E. Park and Ernest Burgess, propagators of fieldwork, inspired their students who conducted investigations of Chicago urban life to apply observation as a data collection method (Węgleński 1983; 1988; Szacki 2005; Czekaj 2007:163). Their Introduction to the Science of Sociology (Park and Burgess 1921), ennobling field research by "making it a fully-fledged academic undertaking and the foundation of sociology as such," remained the basis for the theoretical preparation of sociologists throughout the interwar period (Szacki 2005:604 [trans. AK and KTK]). And, for Polish readers, this work was accessible thanks to Florian Znaniecki, who published its translation, Wrowadzenie do nauk socjologii in 1926 (see also: Wincławski 2012:5).

Before that, Florian Znaniecki (1882-1958) and William I. Thomas (1863-1947) made a landmark study on migration. Their book, The Polish Peasant in Europe and America (1918-1920 [1958]), was one of the most influential pieces using qualitative research (Sinatti 2008:2, 5; Stanley 2010:141; see also: Blumer 1969:117) that offered the analysis of personal life-records (letters between family members sent to the newspapers, the documents of associations, the autobiographies, the life histories), and-according to the authors-these were excellent sociological materials. Using them was an important methodological innovation since the combination of such data has not been applied in any sociological study before.

The qualitative analysis of personal documents elucidated that attitudes and actions are shaped 
by social and cultural milieus (Sinatti 2008:7). Znaniecki and Thomas also disclosed that an individual's actions are shaped by how their personality, social attitudes, and situations are interconnected (Thomas and Znaniecki 1976; Konecki 2017). Moreover, in their opinion, a social analysis should be focused on social change, since biographical and personality changes accompany it. Still, according to Znaniecki, a person is immersed in the culture. Thus, an innovative or a changing self could only happen within this culture (Hałas 1983:350). For Znaniecki, what is essential for action (interaction), are cultural values and systems of norms (Hałas 1983:350; see also: Kaczmarczyk 2020). His orientation is not only interactive but also normative and culturalistic. What separates his point of view from Blumer's is that in Znaniecki's approach the norms are already given in the cultural context. Whereas, in Blumer's view, it is the individual who creates them situationally and actively refers to them in their interpretations, contestations, and redefinitions. This seemingly minor difference paved, in effect, the way for conceptual differences in theorizing about the social world by successive generations of Polish social researchers. Not all of them developed approaches typical for Blumerian SI.

When it comes to life histories analysis, the crucial point is the concentration on the processual aspects of social phenomena (e.g., the process of adjustment and social organization, the process of changing family forms, etc.). The authors of The Polish Peasant have shown that qualitative sociology treated processes as "subjects" of the research, what allowed following the changes (e.g., the sequence of events in the becoming process) and to determine the "subjective meaning," as well as how one's definition of the situation is impacting upon diverse processes. The Polish Peasant and other works of Znaniecki, ${ }^{2}$ as well as his activities promoting the use of personal documents in social research, defined the development of qualitative sociology and marked the scope of substantive areas of rural and urban sociology, sociology of nation (Konecki et al. 2005), including the sociology of migration (Sinatti 2008; Dolińska 2020; Fiń 2020), and the development of biographical methods in sociological research (Schütze 1983; Włodarek and Ziółkowski 1990). Thomas and Znaniecki belonged to the Chicago School of sociology. At the beginning of the $20^{\text {th }}$ century, not only the method of personal documents has been developed by the disciples from the Chicago School but also field studies, nowadays called field research or sociological ethnography (Konecki 2017). The social mapping of the cities was another important tool of research, and social diagnosis implemented by the scholars from the University of Chicago (Czekaj 2007:183, 205-229), and one can notice the influence of the methods of mapping in the situational analysis by Adele E. Clarke (2003; 2005).

The reception of the Chicago School and later SI sociology was strongly connected with the works of Znaniecki, especially the one produced in collaboration with Thomas-The Polish Peasant (Kaczmarczyk 2018). It has created the intellectual atmosphere for the subsequent reception of the SI in Poland. The concepts of the definition of the situation, the definition of the self, and/or joint action were easier to accept knowing the works published

\footnotetext{
${ }^{2}$ Among them should be mentioned: Cultural Reality (1919), Introduction to Sociology (1922), The Laws of Social Psychology (1925), two volumes of Sociology of Education (1928; 1930), The City in View of Its Inhabitants (1932), The Method of Sociology (1934), Social Actions (1936), The Social Role of the Man of Knowledge (1940), Cultural Sciences (1952), or Social Relations and Social Roles (1965).
} 
by Znaniecki and the group of his collaborators. The interest in the subjective, situational, cultural, and personal approach in studying the communities was popular since the very beginning of institutional sociology in Poland. It was under the influence of Znaniecki, who laid the foundations of Polish sociology and, at the same time, personified the link between the American and the Polish sociology schools. His influence on Polish sociology was through his endeavors, important methodological publications (Znaniecki 1934; 1976), as well as his organizational work. In 1920, he established the first Institute of Sociology in Poznan (Dulczewski 1992; Czekaj 2007), creating the Department of Sociology and Philosophy of Culture, and started his famous sociological seminar under the same name (Dulczewski 1992:140). By founding "a school of theoretic and applied sociology," Znaniecki introduced the idea of "gathering and elaborating" sociological materials on Polish soil. Being highly interested in the autobiographical method, he invented a new way of collecting personal materials through memoir-writing competitions. In 1921, he announced the first memoir contest addressed to physical workers and received 149 autobiographies. The success of that first competition gave way to the forthcoming "social memoirs" (pamiętnikarstwo społeczne). Collecting autobiographical writings as a form of developing knowledge about contemporary society became a very popular method of data gathering in Poland. In the interwar period, the memoir competition shaped under the influence of such great Polish scholars as Florian Znaniecki, Ludwik Krzywicki, Józef Chałasiński, Jan Szczepański brought a monumental collection of diaries: by youth, peasants, emigrants, physical workers, miners, teachers, social activists, physicians, new professionals, the unemployed, and other social categories.
Eleven years after the publication of The Polish Peasant, Znaniecki's student and close associate, Józef Chałasiński, continued his mentor's inquiries. In his habilitation, The Ways of Worker's Social Advancement (Drogi awansu społecznego robotnika) published in 1931, he elaborated on autobiographies collected during the first memoir contest (1921) organized by Znaniecki. Directly pointing to the close methodological and thematic relationship linking his analysis with the work of Thomas and Znaniecki, Chałasiński emphasized that:

Only autobiographies allow us to learn about those aspirations that underlie the social advancement of an individual. They tell us about what people in a given environment consider to be a social promotion (a social distinction), to improve their social position and what they are satisfied with, in this regard. Finally, they, and only they, allow us to understand the role of the social environment and various social institutions in the social advancement of individuals, in the shaping of their social consciousness. No other material, however significant from a different cognitive standpoint and helpful for a sociologist, can replace the autobiography in this respect. Economic data tell us about the objective, factual structure of society, or its classes. However, they do not say anything about what this structure is in the social consciousness of groups, what meanings it has for the social aspirations of people, and their collective life. [Chałasiński (1931) 1979:20 (trans. AK and KTK)]

Chałasiński applied this method in his subsequent studies on peasant and working class. As a result of the competition announced in 1936-1937 by the Editorial Board of the magazine Agricultural Training, 1,544 memoirs were obtained from young rural activists all over Poland. The topic of this competition was "A Description of My Life, Work, Plans, 
and Hopes." In 1938, based on these autobiographical materials, Chałasiński published a monumental four-volume work entitled Młode pokolenie chłopów (The Young Generation of Peasants). Znaniecki wrote the Preface to this book, stating that:

Sociologist studies, "the mutual influence, development, transformation, and decay of social forms, modes of action and functions, or, in other words, ways of adapting social groups to new and changing living conditions"...For this kind of sociological analysis, autobiographical material is the best material. It describes the author's social situations, as well as their attitudes and actions in these situations. The subjectivism of this material is therefore not a weakness, but an advantage, because the attitudes and aspirations of an individual and their behavior are not the result of objective, but subjective situations. An individual's responses relate not to the situations as they are independent of the individual, but to how the acting individual sees them. An individual's starting point is their definition of the situation in which they find themselves. [Znaniecki (1938) 1984:XXXII-XXXIII (trans. AK and KTK)]

This way Znaniecki's student implemented the idea of the humanistic coefficient in the study on the young Polish generation of peasants, their life, and struggles for the advancement in social position. Education was one of the agents of the liberation of the young peasants from the shackles of the local community and assigned social position.

Chałasiński knew the American pragmatists' works, which was evidenced by his article Dewey as a Democracy Educator (Chałasiński 1927). Following his teacher and mentor in sociology, Chałasiński also visited the United States of America. In 1931-1933, using a scholarship received from the Rockefeller Foundation, he conducted studies on Polish eco- nomic emigration and the American education system. The fruits of these studies are two monographs in Polish: Parish and Parochial School among Polish Immigrants in America (1935) and The School in American Society (1936). However, it is difficult to find direct references to George $\mathrm{H}$. Mead and Herbert Blumer in his works. The influences of pragmatic thought permeated rather through the works of Thomas and Znaniecki, concerning the personal and subjective view of social reality, and possibly through the works of Dewey, if we think about the educational reflections and democracy. The works of Znaniecki and Chałasiński were not called "symbolic interactionist" neither by them nor by others, but they bore the hallmarks of this way of thinking about social reality in Poland and created the grounds for the reception of SI perspective.

The relation of Znaniecki's concept of the humanistic coefficient with the assumptions of SI is more problematic (Hałas 1983). However, their influence on the biographical studies was immense. The memoir's competitions invented and implemented by Znaniecki became a very popular method of gathering the empirical material for sociological analyses. Before World War II and later, they were widely used by social researchers in Poland to reach various professional and occupational groups (Chałasiński 1971; Szczepański 1976). Between 1921 and 1966, there were over 300 memoir contests organized in Poland (Jakubczak 1966:3).

With time the memoir competition created the basis for the development of the approach being recognized as "the Polish method," which was founded on methodological directives worked out by Florian Znaniecki and Ludwik Krzywicki concerning the use and analysis of diaries. Franciszek Jakubczak describes this method as characterized by: 
1) scientific, materialistic theory of social reality and the laws of social development, 2) recognizing memoirs as an adequate image of social reality and valuable source of materials, showing in harmonious connection the facts of consciousness and facts in the field of material living conditions and objective social relations, 3) practical implementation of the principle of binding and mutual verification of diary research with empirical field research, 4) applying to diaries, apart from the sociological principle of content analysis, also the economic and statistical method of analysis-regarding relevant indicators on a national scale, 5) the principle of social service in publishing the authentic auto-chronicles of representatives of the working classes, to illustrate their actual situation and spiritual face, and to shape the awareness of society and link the workers and peasants' culture with the national culture. [Jakubczak 1989:265 (trans. AK and KTK)]

According to Ludwik Krzywicki, the diaries' analysis represents the principle of social service-the authentic working-class' narratives are published to illustrate their actual situation and social awareness (Jakubczak 1989). In his understanding, the Polish method assumed clear principles of diaries analysis. First, all the content of a single diary should be complexly analyzed. Then, its content is compared with other diaries in the collection. If any previous particular collection exists, a comparative historical analysis is applied. Next, the diary is contextualized with statistics and economic data related to the studied problem. All the materials should be considered regarding the accomplishments of contemporary sociological knowledge and general knowledge in the field of a studied research problem. As a rule, during the analysis, the personal experience of the researcher and professional knowledge of the diary's author should be taken into account. And, finally, Krzywicki recommended the principle of complex, humanistic content analysis in which the evidence for descriptions and generalizations are: (1) excerpts from diaries; (2) diaries presented in extenso in the appendix; (3) the entire collection of diaries in a particular study (Jakubczak 1989:265-266).

Although the influence of Thomas and Znaniecki, and after them, Znaniecki's students, on the further development of qualitative sociology in Poland could be argued and discussed (Szczepański 1976; Konecki et al. 2005), there is no doubt that Znaniecki not only founded but also practically formatted the Polish sociological scene, delineating the way of thinking about sociological research and conceptualizing social reality. For a long time, his works imposed themes and methods of social research and were a kind of mediator between the legacy of the Chicago School and the cradle of the Polish sociology. This influence faded with the decline of qualitative methods and the rapid development of the quantitative approach, survey research, and statistical methods of analysis, which began to dominate in the Polish sociology from the 1960s. ${ }^{3}$

\section{Inspirations and Translations}

From the 1960s, the reception of the still-developing thought of SI was mainly mediated by the original works of Western researchers or by their translations. ${ }^{4}$ In the 1970s, among the classical texts of SI translated to Polish, the Polish audience had access

\footnotetext{
${ }^{3}$ Already in the 1950s, Chałasiński was accused of absolutizing the personal document method and overestimating the role of memoirs as a source for sociological research (Drozdowski 1970:123).

${ }^{4}$ We should remember that the first translation of the monumental work of Thomas and Znaniecki (1918-1920) to Polish was published by Ludowa Spółdzielnia Wydawnicza only in 1976. It was late but provided Polish scholars with a more friendly reading of this classical book.
} 
to the translation of G. H. Mead's work Mind, Self and Society (1932 [1975]) and H. Blumer's text, The Sociological Implications of Thought of George H. Mead (1975). In 1977, a translation of the part of Erving Goffman's Frame Analysis appeared (Łapiński 1977). And in 1981, the translation of Goffman's book, The Presentation of Self In Everyday Life (1959) by Helena Datner-Śpiewak and Paweł Śpiewak, was published. This work, which is the basics for the dramaturgical perspective in sociology, addressed both the issue of identity/self and the interactive involvement of the individual and the group in the presentation of the self. The work was based partly on ethnographic research, as well as SI inspirations, and thus gave some incentives for ethnographic research of interactions, defining the self and others in specific situations and cultural conditions. It was an important piece of work for Polish sociology. A similar inspiration for Polish researchers was another translated work of Erving Goffman, On the Characteristics of Total Institutions (1975), based on ethnographic research and formal analyses of various documents. This text about total institutions, together with The Presentation of Self in Everyday Life, inspired the Polish sociologists in their research and analyses of identity presentation processes, and identity changes (see, e.g., Konecki 1987). Those two works by Goffman seemed to be the most popular references for the sociologists oriented to interactionism in general and to SI in particular at that time in Poland. ${ }^{5}$

\footnotetext{
${ }^{5}$ We are aware that the relation of Goffman with SI is problematic. He does not define himself as a symbolic interactionist at all. However, his early works, especially The Presentation of Self in Everyday Life referring to Everett Hughes and Howard Becker; Asylums taking inspirations from Everett Hughes; Stigma discussing the issues of identity and referring to Howard Becker, all of them testified to the fact that Goffman, indeed, drew inspirations from SI and entered into a dialogue with its conceptions. He used, for example, the concept of "moral career" (in the books Asylums and Stigma). Generally, the idea of a career, especially the moral career, indicates the processual character of the biographical work that is done by
}

There were not many translated works in the field of SI at the turn of the 1970s and 1980s (Blumer 1975; Blumer 1984), mainly fragments, seldom the whole works. Numerous translations appeared only in the next century, after 2000 (Goffman 2005; Blumer 2007).

For a long time in Poland, the reception of SI was possible mostly in English, while research and analyses were mainly conducted in Polish. Therefore, the introduction of symbolic interactionist notions was implemented through translations of the concepts during their application in particular empirical research.

The translations of theoretical works were also important so that the terminology of SI, as well as pragmatic progenitors of this orientation, could be used to develop the theory (Hałas 1994). The erection of theoretical concepts and the work of analyzing empirical materials, or biographical studies (Kaźmierska 2004), permeated each other, weaving the knots of the SI paradigm. We can notice some influences of SI in biographical research, ${ }^{6}$ especially regarding the concepts of Anselm Strauss ([1959] 2013; 1993) related to the biographical work, the transformation of identity, or immersion in specific social

the subject. "Definitions of the situations," along with the biographical path's changes and the "the definition of the self" shifts indicate some relations to SI too. We can also find the "identity ambivalence" as an important topic of the work of symbolic interactionists and also Erving Goffman's. So, we can see some common theoretical interests in the perspectives of SI and Erving Goffman, in his early works. However, we should also indicate that his perspective is aimed at deciphering the formal features of interactions (especially in ritual interactions), their types, and their structures. The later works of Goffman are more structurally oriented than the earlier ones.

${ }^{6}$ The main publications presenting a comprehensive lecture on biographical methods in Poland were works edited by Jan Włodarek and Marek Ziółkowski (1990), and later by Kaja Kaźmierska (2012a). 
worlds (Kaźmierska 1999; 2008; 2012b; Rokuszewska-Pawełek 2002; Kaźmierska, Piotrowski, Waniek 2012). ${ }^{7}$

However, Elżbieta Hałas writes about "the uncertain status of biography in the orientation of symbolic interactionism" (1990:198 [trans. AK and KTK]), pointing out that biographical (auto)reports, while being recommended by symbolic interactionists (Becker 1966; Blumer 1969; Denzin 1970), do not provide access to those aspects of the social process on which SI focuses its attention, that is, to current communication processes as a mutual interaction. Hałas (1990:199) comments on the significant neglect in using the biographical data in SI due to the perceived advantages of the interview and participant observation-considered the best methods and preferred in this approach. On the other hand, she expresses regret that central categories of SI, constructing and negotiating interaction order, relate only to cognitive processes, and yet "experience has richer dimensions than just meaning," and "understanding can never be reduced to rational comprehension" (Hałas 1990:201 [trans. AK and KTK]). ${ }^{8}$

\footnotetext{
${ }^{7}$ In analyzing the interactions between the Polish narrators and the Soviets and Germans as occupiers, in her book The War Experiences of Poles (1999), Kaja Kaźmierska used Strauss's concept of the awareness contexts, as well as the concept of identity developed by this author in Mirrors and Masks (1959). Also, studying the experiences of the Shoah survivors (2012), she referred to the identity, the sense of biographical continuity, and biographical work. In her research on war narratives of Poles, Alicja Rokuszewska-Pawełek (2002) invokes the Straussian concept of trajectory and uses it analytically to individual and collective processes in a sense given to it by Fritz Schütze.

8 The author indicates the usefulness of the symbolic interactionist perspective for research on changes in biographical experience, especially those deliberately carried out, such as in the case of political indoctrination, religious conversion, or psychiatric therapy (Hałas 1990:206). Generally, however, she accuses contemporary SI of excessive formalism, limited interest in the issues of values, and the historical dimension of social life (Hałas 1990:202-203), emphasizing that humanistic sociology is not only a cognitive endeavor but also a moral one (Hałas 1990:206).
}

The achievements of the Polish school of biographical research with the use of personal documents could be included in the interpretative paradigm, although with some reservations (see: Wilson 1970; Czyżewski 1984; Piotrowski 1998:3). SI has certainly given strong inspiration for the research on the relationship between biography, the definitions of identity, and transformations (Piotrowski 1985; 1998:47; Bokszański 1986; 1989). These issues were addressed by Polish sociologists in the 1980s (Ziółkowski 1981) and later, especially among scholars from the Institute of Sociology at the University of Lodz (Czyżewski 1984; 1986; Bokszański 1986; Piotrowski 1998). Theoretical foundations for the analysis of identity processes were created, reaching for interactionist inspirations, including SI (Strauss 1959). Identity transformation processes were analyzed (Bokszański 1986), as well as identity models in SI (Iowa School and Chicago School in SI; Bokszański 1989; Piotrowski 1998:55).

SI was also presented in light of other theoretical orientations, such as phenomenological sociology and ethnomethodology (Ziółkowski 1981; Czyżewski 1984). These studies later resulted in research on the language of the description of experiencing the world in biographical research (Kaźmierska 2008) and discourse analysis (Czyżewski, Dunin, and Piotrowski 1991; Czyżewski, Kowalski, and Piotrowski 1997). On the other hand, symbolic interactionist research developed in various places in Poland, especially in the Department of Sociology of Organization and Management at the University of Lodz. These studies more concerned the social practices and experiencing social worlds than only analyses of the language. ${ }^{9}$

\footnotetext{
${ }_{9}^{9}$ On the issue of experiencing and experiences in social research, see: Anna Wyka (1993), and for the analyses of the relation between the language and the society, see: Andrzej Piotrowski (1986).
} 


\section{Theoretical Elaborations}

In the 1980s, an extremely important book that popularized symbolic interactionist tradition in Poland was the work of Elżbieta Hałas (1987; then from the Catholic University of Lublin), The Social Context of Meanings in the Theory of Symbolic Interactionism, which started from the analyses of the social context of meanings in the SI theory. The author referred to the idea of the humanistic coefficient by analyzing the concept of meaning in Znaniecki's works, and its relation to the concept of meaning in various approaches in SI. Like researchers from the Institute of Sociology of the University of Lodz, she tackled the issue of identity and also analyzed in detail the relation between the concept of identity and the social role. Hałas (1992; 1994; 2001) developed many issues in which she undertook SI, and published many works on this subject. Her contribution to the development of SI in Poland was very significant. She developed and elaborated on the concept of conversion-an extremely interesting interactionist problem, one of the types of identity transformationand showed it in a broader anthropological and historical perspective (Hałas 1992). She brought the Chicago School classics to the students by publishing the elaboration of three important progenitors of SI, Ch. H. Cooley, G. H. Mead, and H. Blumer, and also translations of selected texts of the above-mentioned classical interactionists (Hałas 1994). Theoretical inspirations and issues undertaken by SI can also be observed in other works of the author (Hałas 2001).

A little bit earlier an important elaboration of Cooley's works was published by Janusz Mucha (1992), and some translations of his classical texts appeared. Another significant author who familiarized the Polish reader with SI was Ireneusz Krzemiński from the University of Warsaw. He wrote a book about the connection between SI and sociology, analyzing Mead's influence on sociology, and later on Blumer's thoughts. He also considered other researchers' influences (Krzemiński 1986). He used the inspirations from SI in his research and theoretical deliberations about the Solidarity movement in Poland (Krzemiński 1997; 2013; 2016).

The concepts of SI were later developed by other authors, who attempted to link and understand the ideas of SI from the point of view of other theories or to analyze SI from a critical perspective (Tittenbrun 1983). Grażyna Woroniecka ([1998] 2003) tried to connect hermeneutics and the notion of pre-understanding with symbolic interaction. She analyzed how the actor's subjective point of view is related to and translates into the intersubjective world of communication. An introduction to more contemporary variants of the epistemology of SI was provided by Anna Kacperczyk (2007a; 2007b; 2016a) in her attempts to review, discuss, and critique the approach defined as "situational analysis" by Adele E. Clarke (2003; 2005). Fundamental theoretical analyses of social situations from the perspective of SI were done by Aleksander Manterys (2000; 2008), who critically elaborated on the limitations of some classical symbolic interactionist concepts that apply the negotiation perspective to the analysis of social situations and the definitions of the situations. Also, Piotr Sztompka (2005) introduced the SI perspective to the visual research describing interactionist and symbolic interactionist inspirations and possibilities in using the photographic method in sociological research.

All of these activities gave the students of sociology a chance to get acquainted with historical, theoretical, and empirical works created in the interpreta- 
tive paradigm, and offered new circumstances for the further development of SI in Poland, especially after the year 2000 .

\section{Learning about SI through Translations and Doing Research}

As already mentioned, many books on symbolic interaction were translated in the years 2000 and later. They were not only very helpful in the development of an empirical trend in SI in Poland but also in establishing the interpretive paradigm. Considering the interactionist perspective, there were mainly translations of Erving Goffman books in Poland at that time. In the beginning, we only mentioned those items in Goffman's oeuvre which were most similar, although in part, to the orientation developed by Mead and Blumer. So, we now mention the translated books: Stigma ([1963] 2005), Interaction Ritual ([1967] 2006), and Asylums ([1961] 2011).

The translation of the original Blumer's work Symbolic Interactionism ([1969] 2007) by Grażyna Woroniecka was quite a late achievement of Polish sociological translations, although very important. It certainly helped to teach students on this perspective and provided epistemological foundations of SI. Finally, the translation of Mirrors and Masks ([1959] 2013) improved the reception of the concept of identity in SI. Moreover, the publication of Awareness of Dying (Glaser and Strauss [1965] 2016) was a very practical and methodical example of using the field study for the analysis of interaction and awareness contexts in the interactions.

Since Polish scholars could study SI easier having the main concepts of the orientation in their native language, it was also easier for them to use these concepts in the research conducted in Polish. Un- dertaking the investigation process in the frame of SI allowed strengthening this approach and implementing it in theorizing on social reality. Learning on social reality meant for Polish researchers to do extensive field studies, ethnographical research, and analyzing thick data. A very important role in assimilating the perspective of SI in Poland was the familiarization of Polish researchers with the procedures of the grounded theory methodology, which transferred into the field of empirical research many assumptions and general interpretative framework of SI.

Concerning empirical research, two translations were very helpful and important in the field study and analysis of qualitative data. One was Glaser and Strauss's book Discovery of Grounded Theory ([1967] 2009), and the other one was Constructing Grounded Theory ([2006] 2009) by Kathy Charmaz. These two, very inspiring and constructive, books helped propagate not only qualitative research and data analysis but also SI as a paradigm since the roots of grounded theory can be traced to Blumer's processual vision of reality and Straussian negotiated order of social reality (Konecki 2000). From 2008 Polish readers could get acquainted with the ordering of different varieties of the grounded theory from the book Procedures and Emergence by Marek Gorzko (2008).

But, before that, for many years, Polish researchers had access to only a few works on the subject of grounded theory methodology. Before 2000, there were only two published works available for Polish readers that addressed grounded theory: Konecki's (1989) “The Methodology of Grounded Theory in the Research of the Situation of Work" and the paper by Zakrzewska-Manterys (1996) "De-Theorizing of Social World. Basics of Grounded Theory." Both authors emphasized not creating the theory before the 
gathering of the data in empirical research. In 2000, the book Studies in the Methodology of Qualitative Research. Grounded Theory was published by Konecki. It was a manual that indicated the connection between grounded theory and SI (Konecki 2000:32-47), spreading the idea of qualitative research in Poland. The book became a set of indispensable tools for the sociologist using qualitative methods of research and data analysis, and the interpretative paradigm (Bukalska 2019).

Some of the important translations for the development of SI in Poland appeared in the journal Przeglad Socjologii Jakościowej. It was the paper by Robert Prus, "Drinking as Activity. An Interactionist Perspective" (2007). ${ }^{10}$ The author shows that drinking alcohol is situationally and interactionally conditioned and constructed. Another translated text by the same author traces the pragmatic themes, thoughts, and symbolic interactions creating the communities in ancient poetry (Prus 2011).

There were also issued the translations of the very important interactionist works that helped to broaden the view of contemporary interactionist orientations and especially the methodology and epistemology of SI. The Polish translation of Charmaz ([2006] 2009) gave support to the constructivist approach in methodology that was implicitly included in Anselm Strauss's works. Here, the perspective of SI in the methods of research has been highlighted.

Kathy Charmaz also directly referred to the symbolic interactionist and pragmatist inspirations in her constructivist approach in grounded theory (Charmaz 2006:7, 22). She looked for the Chicago School

\footnotetext{
${ }^{10}$ This article originally appeared in 1983 in the Journal of Studies on Alcohol 44(3):460-475.
}

legacy in the approach of Anselm Strauss as he was one of the founders of grounded theory methodology. The concepts of enacting change, meanings, and the construction of reality, the self, and society in an interaction could be found in the grounded theory epistemology and methodology.

\section{Institutionalization}

A very important feature of the development of SI in Poland was the institutionalization of the research interests and channels of communication. During the XII Congress of the Polish Sociological Association in 2004 in Poznan, the thematic group "Constructing of Self and Society. The European Variants of Symbolic Interactionism" was created. The sessions of this group were very popular, and the effect of deliberations and discussions was the publication of the book in Polish, edited by Elżbieta Hałas and Krzysztof Konecki (2005), under the same title as the name of the group. The book summed up the research and analyses that were undertaken at that time on SI by Polish scholars.

Also the year 2005 was important for the development of SI in Poland because in this year in the Polish Sociological Association the section under the name Qualitative Sociology and Symbolic Interactionism ${ }^{11}$ was created. The section started to organize conferences and lectures on SI and qualitative research. A few years later, it also started the competition under the name of Anselm Strauss awarding the best Polish symbolic interactionist publication of the year. ${ }^{12}$

\footnotetext{
${ }^{11}$ Information about the section is available at: https://pts.org. pl/en/sekcje/sekcja-socjologii-jakosciowej-i-si/.

${ }^{12}$ Katarzyna Kowal received the award for the article "Między ziemią a niebem... Doświadczanie własnej cielesności przez osoby praktykujące podwieszanie ciała - studium socjologiczne [Between Earth and Sky...Experience of Own Corporeality by
} 
In 2012, the members of the section accomplished a collective work by publishing the Dictionary of Qualitative Sociology (Konecki and Chomczyński 2012) with many entries referring to SI, such as: sociological ethnography, front stage, total institution, constructivist grounded theory, biographical method, accounts, biographical work, articulation work, social world, techniques of neutralization, labeling theory, identity, trajectory, generalized other, humanistic coefficient, significant other.

The section collaborated with the Qualitative Network of European Sociological Association, and in 2016 organized the conference "Qualitative Methods and Research Technologies" in Cracow. The topic of that conference corresponded with other events held by the section, whose interest embraced the issues of: social worlds and subcultures, new methods of qualitative research, qualitative research and pragmatism, the teaching of qualitative methods, et cetera.

In 2017, in cooperation with the European Society for the Study of Symbolic Interaction, the section organized another international event, the conference "Studying Everyday Life. Generic Dimensions of Interactionist Inquiry" (July 04-08, 2017) held at the University of Lodz. The event aimed "to provide an interdisciplinary and international forum within which to utilize and extend symbolic interactionist theory and methods in the thick description and exploration of human lived experience,"13 and was

People Practicing Body Suspension-Sociological Study]." 2018. Przegląd Socjologii Jakościowej 14(2):84-119, and Honors went to Katarzyna Kalinowska for the book Praktyki flirtu $i$ podrywu. Studium z mikrosocjologii emocji [The Practices of Flirting and Pickup. A Study in the Microsociology of Emotions]. 2018. Torun: Wydawnictwo Naukowe Uniwersytetu Mikołaja Kopernika.

${ }^{13}$ Full information on the event is available at: https://www.britsoc.co.uk/umbraco/plugins/umbracoContour/files/631209c6532e-4f02-a832-c9e14e6fec63/CFP_2017_EUSSSI_1_.pdf. a great opportunity to meet researchers from Europe and North America and to discuss the ways in which empirical endeavors of SI contribute to a more generic understanding of human group life.

A vital element of the institutionalization of the symbolic interactionist approach in Poland was the creation of the journals with the mission of connecting researchers who work in this tradition, "for whom interpretative paradigm and qualitative research methodology are basic perspectives of studying social reality, in order to enable a free flow of information and to integrate the community of qualitative sociologists," as states the flyer on the cover of every issue of the Qualitative Sociology Review. ${ }^{14}$ In fact, the Department of Sociology of Organization and Management at the University of Lodz created two journals with that mission, one is the Qualitative Sociology Review, which publishes papers in English, and another is Przeglad Socjologii Jakościowej that publishes mainly in the Polish language. Each of these two journals, popular not only in Poland, produces four issues a year. The journals are indexed in many important databases. Many foreign scholars collaborate with the QSR and PSJ journals and support them with their expertise. One of them is Robert Prus from Waterloo University in Canada, who has published many essential papers on symbolic interaction and pragmatic issues in ancient philosophical texts and concepts, for example, referring to Aristotle or Plato (Prus 2013a; 2013b).

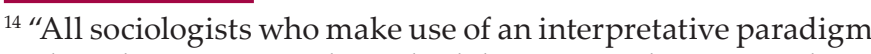
and qualitative research methodology are welcome to submit their articles and support our initiative. We especially welcome researchers who use symbolic interactionism perspective, but also grounded theory, sociological ethnography, autoethnography, phenomenology, ethnomethodology, and who use the methods of observation of actions and analysis of lived experiences." See: http://www.qualitativesociologyreview.org/ENG/ index_eng.php.
} 
Considering the range and scope of symbolic interactionist research projects and published works, it seems that the Department of Sociology of Organization and Management at the Faculty of Economics and Sociology at the University of Lodz remains an important Polish center of symbolic interactionist research (Byczkowska-Owczarek 2012; 2015; Chomczyński 2008; 2014; 2015; 2017; 2018; Dymarczyk 2008; 2018a; Konecki 1987; 1989; 1994; 1997; 1999; 2000; 2005a; 2005b; 2005c; 2007; 2008a; 2010; 2011; 2012; 2014; 2015; 2017; Kubczak 2011; Marciniak 2008; 2016; Niedbalski 2015; 2016a; 2016b; 2016c; 2016d; 2017; 2019; Pawłowska 2012; Ślęzak 2009; 2015; 2017; Wojciechowska 2012; 2015; 2020). Anna Kacperczyk is another scholar from the Institute of Sociology at the University of Lodz connected with this center. Many master's and doctoral dissertations were created there. Several of them were of high quality and received prizes in local and nationwide competitions. ${ }^{15}$

Polish SI has had a strong empirical trend. The growing matrix of executed and ongoing investigations strengthened the world of SI, providing the data for deliberations and theoretical discussions. The communication channels were very important since due to publishing activity, conferences, and workshops created a space for the exchange of thoughts, research experiences, and outcomes.

\section{The Subjects of Empirical Research and Publications}

In the following part of the article, we consider the efforts of Polish researchers studying symbolic inter-

\footnotetext{
15 The following persons' monographs were awarded in the contents welcoming dissertations that used the symbolic interactionist perspectives in the research and analyses: Łukasz Marciniak, Jakub Niedbalski, Piotr Bielski, Marta Zwolińska, Magdalena Wojciechowska, Piotr Miller, Izabela Ślęzak-Niedbalska, Michał Lesiak.
}

action mainly based on the activity of interactionists from the University of Lodz (mainly scholars from the Department of Sociology of Organization and Management and Institute of Sociology). Expressing a view that in symbolic interactionist investigations, the theory, methodology, and empirical data are to be indispensably interrelated and internally linked, we intentionally focus on empirical studies that meet this criterion.

The most crucial orientation used by Polish researchers was the grounded theory methodology, and the main theoretical foundation was SI with strong inspirations from Anselm Strauss's work. Krzysztof T. Konecki (1987; 1989; 1994), who met Strauss personally and studied for one year under his supervision, has been using the grounded theory and interactionist perspective for many years. In the years 1994-1995, Konecki investigated executive search companies in Silicon Valley and consulted the research outcomes with Anselm Strauss during his seminar at UCSF (Konecki 1997; 1999). Although it was not the first application of grounded theory by Konecki, the joint work with Strauss convinced him of the clarity of grounded theory methodology procedures and their applicability in teaching. In 2000, he published the first Polish manual of grounded theory: Studies in Methodology of Qualitative Research. Grounded Theory. The publication of the book encouraged other researchers and students to use grounded theory procedures in their investigations and, above all, gave them tools to make qualitative, interactionist research and empirical data analysis possible. The book, apart from methodological and epistemological considerations, also had an instructive part focused on gathering qualitative data and particular grounded theory analytical procedures. All of Konecki's inspirations coming from Glaser and Strauss's books (Glaser and Strauss 1965; 1967; 
Glaser 1978; Strauss 1987) were not widely known in Poland at that time, thus the first manual in Polish was a very important source for the scholars interested in qualitative analysis of interaction processes.

The following publications of Polish symbolic interactionists were mainly in the Polish language. The publication of the articles-most often reporting the conduct and results of the investigations that used many theoretical concepts applied in the concrete empirical situations and case studies-revealed the ideas that created the general perspective of symbolic interactionist studies. There were the following notions constantly present in these studies: role-taking, self, looking-glass self, the definition of the situation, sensitizing concepts, total institutions, impression management, significant other, shame, pride, and so on.

The methodology of grounded theory was predominantly organizing the course of the study and data analysis process. The method of sociological ethnography prevailed in the fieldwork (Prus 1996; 1997). Techniques of data gathering included: unstructured interviews, observations, participant observations, collecting and/or creating visual data, and collecting documents for analysis as the extant data. The significant methodological publications that helped to improve doing the qualitative research in the SI style were the book by Konecki (2000) on grounded theory and qualitative techniques of research, and by Kacperczyk (2016a) about the methods of research and the analysis of social worlds.

The vital endeavor was undertaken by the journal Przeglad Socjologii Jakościowej that published a series of monographs under the name of "Becoming..." edited by Anna Kacperczyk (Hernik 2007; Konecki 2007; Marciniak 2008; Bielski 2009; Ślęzak 2009; Miller 2010; Słowińska 2010). These were the studies in which the central category was the process of becoming, and thus constructing identity, transforming identity, and understanding it in specific social worlds. These were directly related to the issues and theoretical concepts undertaken by SI, including the issues of labor and occupational sociology (Hughes 1958; 1997). The monographs were published on becoming a new worker in a factory (Konecki 2007), on converting students of theatrical art to an artistic and actors' perspective (Hernik 2007), on becoming an academic teacher (Marciniak 2008), on becoming a poet (Ślęzak 2009), on becoming an organic farmer (Bielski 2009), on constructing the identity of a mountain rescuer (Miller 2010), on constructing identity in the world of carrier pigeon breeders (Słowińska 2010). All of these were related to the analysis of identity, identity work, and identity change. The identity was somehow one of the central categories focusing attention during the analysis of the process of becoming (see: Wagner 2005; 2011; 2015; Kubczak 2011; Mróz 2012; Bunio-Mroczek 2015).

A very interesting contribution to the field of empirical studies in SI was made by Izabela Wagner. She is a Polish-originated scholar, who studied sociology in France under the supervision of a Sorbonne professor Jean-Michel Chapoulie, the specialist of the Chicago School. For this reason, her sociological education included intensive training in qualitative methods, conversance with works of Everett Hughes, Howard Becker, and a strong orientation towards the intellectual tradition developed by sociologists from the Chicago School. Her PhD thesis, La production sociale des violonistes virtuoses (The Social Production of the Virtuoso), was based on ten years of field research and was about the socialization of soloists and the career-making process in the artistic elite world (published in 2015). Wagner continued the ethnographic research of elite professional 
worlds, addressing the problem of scientific elites' migration (2011), and expanding theorizing about biography in the symbolic interactionist frame in her latest book Bauman: A Biography (2020). Besides her interesting field studies on career coupling (Wagner 2005), international mobility of creative professionals (Wagner 2011; 2016), or becoming a violin virtuoso (Wagner 2015), she established an interesting group of researchers inspired by SI in the Institute of Sociology at the Warsaw University. In 2008-2017, Wagner conducted the course "Chicago School and Social Problems" at Warsaw University. She also led the students' research club and supervised their PhD theses. Her students, Beata Kowalczyk and Mariusz Finkielsztein, investigated the identity issues in the processes of becoming and careers. Mariusz Finkielsztein started a very intriguing area of research on boredom. In his PhD thesis entitled On the Social Significance of Boredom. The Phenomenon of Boredom in a University Milieu, he focused on boredom in higher education (Finkielsztein 2017; 2019). He also organized the International Interdisciplinary Boredom Conference in Warsaw. Another young scholar, Beata Kowalczyk, worked on the thesis "Transnational" Art World. Career Patterns of Japanese Musicians in the European World of Classical Music (see also: Kowalczyk 2014; she will soon publish a book [Kowalczyk in press]).

SI as a theoretical perspective, along with the methodology of grounded theory, was used in the research on work, professions, and interactions in diverse workplaces, organizational cultures, and organizational subcultures (Konecki 1994; 2007; Wagner 2005; Dymarczyk 2008, 2018a; Lesiak 2019), and also on professions and educational organizations (Byczkowska 2006). The interests in organizations, management, and economic actions (Konecki 2008b) were meaningful in empirical research. There was research on the social organization of the flea market activities where the interactional tactics were traced, and spatial and social hierarchy, as well as the division of work, were described (Marciniak 2016). The grounded theory and interactionist perspective were also used in analyzing financial markets and the profession of individual investors (Pyfel 2015).

The works worth mentioning are also publications of Anna Kacperczyk (1998; 1999; 2002; 2006) on palliative care that gave the input to the analysis of hospice and palliative care development in Poland through the case study of the care-teams organization and the interaction processes between the participants of the situation of dying where caregivers meet terminally ill recipients and their family. The awareness contexts of the interactions between volunteers, personnel, and dying patients in hospices were investigated. The author reached for the concepts of Glaser and Strauss (1965) that appeared useful in the analysis of the interactions in the terminal situations.

Another interesting research study was done on stigmatization and deviance. For example, there was the analysis concerned mainly with the micro-level and the workplace as the terrain of creating the victim in the process of mobbing (Chomczyński 2008). The point of view of participants was widely represented and workable categories of analysis were created based on their narrations. The concepts were also associated with the issue of professions and work. There were essential researches on prostitution and escort agencies that used the concepts of stigma and work on identity (Wojciechowska 2012; 2015) and the concepts of work (Ślęzak 2015), but also the category of violence in sex work (Ślęzak 2017). Magdalena Wojciechowska also analyzed the identity work (normalizing practices) among non-heteronormative women partners having chil- 
dren (Wojciechowska 2020: chapters 7 and 8). The influence of concepts from SI is noticeable in these works (Strauss 1993; Prus and Grills 2003).

The problems of rehabilitation connected with stigmatization and deviance were also developed in the research. SI was connected with cognitive-behavioral theory and situational action theory, especially in pedagogy (Bernasiewicz 2011; 2012; 2017). There was also a field study of youth shelters and correctional facilities that analyzed interactions between staff and inmates (Chomczyński 2014) and between the correctional facilities' charges (Chomczyński 2015).

Social rehabilitation was also in the center of interests of another symbolic interactionist researcher, Jakub Niedbalski (2015), who researched on interactions of personnel with mentally handicapped charges in social welfare homes. His interests later evolved in the direction of sport and the sociology of the body, when he studied sports practiced by people with disabilities and analyzed psycho-social rehabilitation by sport (Niedbalski 2016a; 2016d). The author also analyzed the careers of disabled sportspeople from the symbolic interactionist perspective (2016c).

The latest, very important development was in the research on the body and embodiment. Although it seemed to be a forgotten or taken-for-granted dimension of interaction in symbolic interactionist studies, the body remains an indispensable part of social settings and interactional situations. The analysis of the body was conducted in the following subjects: the interaction of humans with animals (Konecki 2005b), the body practice and embodiment in dance (Byczkowska 2012; Byczkowska-Owczarek 2015), the hatha-yoga practice (Konecki 2015), climbing (Kacperczyk 2012; 2013; 2016b), and in the sport of disabled persons (Niedbalski 2016c). The notion of interaction was important in all the aforementioned terrains of study, and in climbing, it was also analyzed as the interactions with material objects and with inanimate nature (Kacperczyk 2016a).

Another important topic was connected with the arousal of emotions in interactions (Pawłowska 2012; Pawłowska and Konecki 2013). There were publications that related to the theoretical issues of emotions in SI, the elaboration of Theodore Kemper's theory (Pawłowska 2014), and Thomas Scheff's theory (Konecki 2014). But, there also were researches on the emotions experienced in many diverse situations, interactions, and organizations, as in teachers' work, hatha-yoga practice, climbing, and correctional homes (Pawłowska and Chomczyński 2012; Kacperczyk 2013; 2016a; Chomczyński 2014; Pawłowska and Konecki 2014).

The development of the visual analysis in the SI style can be seen as an achievement of the Polish SI brand. The elaboration of the visual grounded theory was one of the moments that advanced the visual analysis (Konecki 2005c; 2011). The constructivist flavor dominated the study. Among the various visual artifacts that had been researched and analyzed were photos of the interactions of animals and humans (Konecki 2005b), video recordings (Konecki 2008a; Byczkowska 2012), and war posters (Ferenc, Dymarczyk, and Chomczyński 2014). One of the researchers in visual studies is Waldemar Dymarczyk (2008), who published one of the first visual analyses based on grounded theory. His analysis of the war posters aroused a big interest on the Internet (Dymarczyk 2014). He also analyzed the use of esthetics and fascists symbols in the contemporary iconosphere (2018b). 
By discussing the examples of the work and achievements of one research center in Poland (located at the University of Lodz) that concentrates activities and investigations of scholars and enhances their efforts by the operation of the Section of Qualitative Sociology and Symbolic Interactionism of the Polish Sociological Association and two important journals, we tried to show the diversity of investigated areas and analyzed topics in the symbolic interactionist perspective, and, at the same time, its internal coherence.

\section{Conclusions}

In Poland, we can differentiate two trends in the development of SI. One is connected with early theoretical elaborations of the orientation and translations of the classical books of SI, and another is mainly connected with empirical research that used SI concepts and the grounded theory approach to investigate social reality.

The translations of classical books in symbolic interactionist tradition to Polish were slightly late. The majority of them were done after the year 2000. However, this does not mean that the reception of SI was not possible earlier without these translations. Some Polish theoretical elaborations that analyzed in detail the classical texts of SI and the pragmatist roots of it were available-the thought of SI was intermediated by the works of Ziółkowski (1981), Tittenbrun (1983), Czyżewski (1984), Piotrowski (1985), Bokszański (1986; 1989), Hałas (1986), Krzemiński (1986; 1997). However, the translations were a very important element of influencing the reception of SI in Poland. The translated books and papers influenced the research and theoretical analysis practice of the scholars. The translation of Goffman's works and methodological books on grounded theory was very important in the development of research practice, especially to sociological ethnography and grounded theory methodology as a style of gathering and analyzing data.

The field research that was done in the theoretical frame of SI and the methodology of grounded theory resulted in raising epistemological and methodological reflections of Polish researchers (Konecki 1989; 2000; Kacperczyk 2016a; Chomczyński 2017; 2018; Byczkowska-Owczarek 2019). The methodology that used sociological ethnography as a method (Prus 1996) was elaborated critically also in ethical terms (Niedbalski 2016b; Niedbalski and Ślęzak 2016; Chomczyński 2017). Thus, the empirical trend of SI embedded in extensive field research has been very strong in Poland.

One may conclude that SI in Poland has been developing in many dimensions. Methods, ethical issues, epistemological reflection, and varied topics prove that the growth of SI was dynamic. The inspirations from other theoretical orientations were also noticed. The influence of Bourdieu's theory, Foucault's works, ANT orientation, grounded theory, constructivism, phenomenology, ethnomethodology, and recently autoethnography and contemplative studies is noticeable. Although the combination of many different orientations is difficult to realize, the inspirations from different perspectives are, however, not only possible but perhaps somehow unavoidable. We should stress that the methodology of grounded theory in the version of Strauss (1987) and later Charmaz (Gorzko 2008:403, 407-408) was very important for the researchers who used the symbolic interactionist perspective, and it was a fundamental procedure for the analysis of empirical data.

Finally, we should remember that Znaniecki's works and their continuation by other researchers 
(Chałasiński, Jakubczak, Krzywicki, and others) prepared the ground for the reception of SI in Poland. Their reflections and theoretical solutions still resonate in newer empirical works and contemporary research, combining Polish SI with the Chicago School traditions.

The development of SI was also connected with crossing the boundaries of the perspective. The re-

\section{References}

Becker, Howard S., ed. 1966. Social Problems: A Modern Approach. New York: Wiley \& Sons.

Bernasiewicz, Maciej. 2011. Interakcjonizm symboliczny w teorii i praktyce resocjalizacyjnej [Symbolic Interactionism in Rehabilitation Theory and Practice]. Cracow: Impuls.

Bernasiewicz, Maciej. 2012. "A Symbolic Interactionism Perspective in the Social Rehabilitation Theory and Clinical Social Work." The New Educational Review 29(3):305-315.

Bernasiewicz, Maciej. 2017. “Working with Children at Risk in the Perspective of Symbolic Interactionism (SI) and Situational Action Theory (SAT)." The New Educational Review 48(2):167-176.

Bielski, Piotr. 2009. "Rolnictwo ekologiczne jako zawód i powołanie. Studium tożsamości, organizacji i potencjału rozwojowego polskich rolników ekologicznych [Organic Farming as a Profession and Vocation. A Study of the Identity, Organization, and Development Potential of Polish Organic Farmers]." Przegląd Socjologii Jakościowej 5(3).

Blumer, Herbert. [1969] 2007. Symbolic Interactionism. Perspective and Method. Englewood Cliffs, NJ: Prentice-Hall. Polish translation by Grażyna Woroniecka, Interakcjonizm Symboliczny. Perspektywa i Metoda. Cracow: Nomos.

Blumer, Herbert. 1975. “Implikacje socjologiczne myśli George'a Herberta Meada [The Sociological Implications of the Thought of George H. Mead, originally published in the American Journal of Sociology, 1966]." Translated by D. Niklas. Pp. 7084 in Elementy Teorii Socjologicznej. Materiaty do dziejów socjologii [The Elements of the Sociological Theory. Materials for the Histo- searchers are not dogmatic and broaden the view to find new inspirations and to deepen the approach of SI, as, for example, by using situational analysis (Clarke 2005; see also: Kacperczyk 2007a; 2007b). There is a noticeable turn to autoethnographic research (Kacperczyk 2014; 2017) and contemplative studies in social research (Konecki 2018). We believe that other orientations will enrich SI theoretically and also make its development substantial.

ry of Sociology], edited by W. Derczyński, A. Jasińska-Kania, and J. Szacki. Warsaw: PWN.

Blumer, Herbert. 1984. “Społeczeństwo jako symboliczna interakcja [Society as a Symbolic Interaction].” Pp. 71-86 in Kryzys i Schizma [Crisis and Schism], edited by E. Mokrzycki. Warsaw: PIW.

Bokszański, Zbigniew. 1986. “Koncepcja tożsamości jednostki w pracach Anselma L. Straussa [The Concept of the Identity of an Individual in the Works of Anselm L. Strauss]." Studia Socjologiczne 2:89-110.

Bokszański, Zbigniew. 1989. Tożsamość, interakcja, grupa [Identity, Interaction, Group]. Lodz: Wydawnictwo Uniwersytetu Łódzkiego.

Bukalska, Izabela. 2019. "Recepcja metodologii teorii ugruntowanej wśród polskich badaczy - refleksje 50 lat po publikacji Barney'a G. Glasera i Anselma L. Straussa [The Reception of the Methodology of Grounded Theory among Polish Researchers-Reflections 50 Years after the Publication of Barney G. Glaser and Anselm L. Strauss]." Przeglad Socjologii Jakościowej 15(3):92-114.

Bunio-Mroczek, Paulina. 2015. “Becoming a Teenage Father. Having a Baby as a Turning Point in Biographies of Young Men of Low Socioeconomic Status Inhabiting Poverty Enclaves." Przegląd Socjologii Jakościowej 11(3):68-89.

Byczkowska, Dominika. 2006. “Solidarność zawodowa jako wynik socjalizacji wtórnej. Na przykładzie zawodu lekarza [Professional Solidarity as a Result of Secondary Socialization. The Example of the Medical Profession]." Przeglad Socjologii Jakościowej 2(1):88-110. 
Byczkowska, Dominika. 2012. Ciało w tańcu. Analiza socjologiczna [The Body in Dance. Sociological Analysis]. Lodz: Wydawnictwo UŁ.

Byczkowska-Owczarek, Dominika. 2015. "Socjologia i taniec. Poszukiwanie znaczeń w ruchu [Sociology and Dance. Searching for Meanings in Motion]." Miscellanea Anthropologica et Sociologica 16(1):23-37.

Byczkowska-Owczarek, Dominika. 2019. “The Analytical Procedures of Grounded Theory Methodology in Research on the Human Body." Przeglad Socjologii Jakościowej 15(3):56-69.

Chałasiński, Józef. 1927. “Dewey jako pedagog demokracji [Dewey as a Democracy Educator]." Oświata $i$ Wychowanie 1:12-21.

Chałasiński, Józef. [1931] 1979. Drogi awansu społecznego robotnika. Studium oparte na autobiografiach robotników [The Ways of Workers Social Advancement. A Study Based on the Autobiographies of Workers]. Poznan, Warsaw: Ludowa Spółdzielnia Wydawnicza.

Chałasiński, Józef. 1935. “Parafia i szkoła parafialna wśród emigracji polskiej w Ameryce [Parish and Parochial School among Polish Immigrants in America]." Przeglad Socjologiczny 3(3/4):633-711.

Chałasiński, Józef. 1936. Szkoła w społeczeństwie amerykańskim [The School in American Society]. Warsaw: Naukowe Towarzystwo Pedagogiczne.

Chałasiński, Józef. 1938. Młode pokolenie chłopów. Procesy i zagadnienia ksztattowania się warstwy chtopskiej w Polsce, t. I-IV [The Young Generation of Peasants. Processes and Issues in the Formation of the Peasant Social Strata in Poland, vol. I-IV]. Warsaw: Spółdzielnia Wydawnicza Pomoc Oświatowa.

Chałasiński, Józef. [1938] 1984. Młode pokolenie chłopów, T. I [The Young Generation of Peasants, vol. I]. Warsaw: Ludowa Spółdzielnia Wydawnicza.

Chałasiński, Józef. 1971. "Pamiętnikarstwo XIX i XX wieku jako świadectwo przeobrażeń narodu Polskiego [Memoirs of the XIXth and XXth Centuries as a Testimony of the Transformation of the Polish Nation]." Pamietnikarstwo Polskie 1-4:15-21.

Charmaz, Kathy. [2006] 2009. Constructing Grounded Theory. Practical Guide Through Qualitative Analysis. London: Sage. Polish translation by B. Komorowska, Teoria ugruntowana. Warsaw: PWN.
Chomczyński, Piotr. 2008. Mobbing w pracy z perspektywy interakcyjnej. Proces stawania się ofiara [Mobbing at Work from an Interactive Perspective. The Process of Becoming a Victim]. Lodz: Wydawnictwo Uniwersytetu Łódzkiego.

Chomczyński, Piotr. 2014. Działania wychowanków schronisk dla nieletnich i zakładów poprawczych. Socjologiczna analiza interakcji grupowych [The Activities of Children from Juvenile Shelters and Correctional Facilities. Sociological Analysis of Group Interactions]. Lodz: Wydawnictwo Uniwersytetu Łódzkiego.

Chomczyński, Piotr. 2015. "Problem etykietowania i stygmatyzacji wśród wychowanków zakładów poprawczych i schronisk dla nieletnich. Socjologiczna analiza zjawiska [The Issue of Labeling and Stigmatization among Juveniles in Juvenile Detention Centers and Shelters. Sociological Analysis of the Phenomenon]." Studia Socjologiczne 4(219):205-236.

Chomczyński, Piotr. 2017. “Dylematy etyczne i metodologiczne w etnograficznych badaniach terenowych w Meksyku [Ethical and Methodological Dilemmas in Ethnographic Fieldwork in Mexico]." Roczniki Nauk Społecznych 8(44)4:143-159.

Chomczyński, Piotr. 2018. "Doing Ethnography in a Hostile Environment: The Case of a Mexico Community." Research Method Cases in Sociology, Postgraduate. Retrieved September 28, 2020 (http://methods.sagepub.com/case/doing-ethnography-in-hostile-environment-the-case-of-mexico-community).

Clarke, Adele. 2003. "Situational Analyses: Grounded Theory Mapping after the Postmodern Turn." Symbolic Interaction 26(4):553-576.

Clarke, Adele. 2005. Situational Analysis: Grounded Theory after the Postmodern Turn. Thousand Oaks, CA: Sage.

Czekaj, Krzysztof. 2007. Socjologia Szkoty Chicagowskiej i jej recepcja w Polsce [The Sociology of the Chicago School and Its Reception in Poland]. Katowice: Górnośląska Wyższa Szkoła Handlowa.

Czyżewski, Marek. 1984. Socjolog i życie potoczne. Studium z etnometodologii $i$ współczesnej socjologii interakcji [Sociologist and Everyday Life. A Study of Ethnomethodology and Contemporary Sociology of Interaction]. Lodz: Wydawnictwo UŁ.

Czyżewski, Marek. 1986. “The Social Production of Experience." Polish Sociological Bulletin 3-4:11-21.

Czyżewski, Marek, Kinga Dunin, and Andrzej Piotrowski, eds. 1991. Cudze problemy. O ważności tego co nieważne [Other 
People's Problems. About the Validity of What Doesn't Matter]. Warsaw: Ośrodek Badań Społecznych.

Czyżewski, Marek, Sergiusz Kowalski, and Andrzej Piotrowski. 1997. Rytualny Chaos. Studium Dyskursu Publicznego [Ritual Chaos. The Study of Public Discourse]. Cracow: Aureus.

Denzin, Norman K. 1970. The Research Act. Chicago: Aldine.

Dolińska, Anna. 2020. “Maintaining Close and Intimate Relationships by Migrant Peasant Families at the Beginning of the 20th Century." Italian Sociological Review 10(2S):409-423.

Drozdowski, Marian. 1970. “Spór wokół twórczości Józefa Chałasińskiego [A Dispute over the Works of Józef Chałasiński]." Kwartalnik Historyczny LXXVII(1):117-131.

Dulczewski, Zygmunt. 1992. Florian Znaniecki. Life and Work. Poznan: Wydawnictwo Nakom.

Dymarczyk, Waldemar. 2008. Temporalny wymiar karier menedżerskich [The Temporal Dimension of Managerial Careers]. Katowice: Wydawnictwo Naukowe "Śląsk."

Dymarczyk, Waldemar. 2014. "The War on the Wall. Polish and Soviet War Posters Analysis." Qualitative Sociology Review 10(4):6-31.

Dymarczyk, Waldemar. 2018a. Przestrzenny wymiar karier menedżerów i przedsiębiorców. Analiza socjologiczna [The Spatial Dimension of the Careers of Managers and Entrepreneurs. Sociological Analysis]. Lodz: Wydawnictwo Uniwersytetu Łódzkiego.

Dymarczyk, Waldemar. 2018b. “Siodłata czapka i oficerki. Długi żywot brunatnej estetyki [Crusher Cap and Knee-Boots. The Long Life of Tan-Brown Aesthetics]." Akcent. Literatura i Sztuka 54(4)249-256.

Ferenc, Tomasz, Waldemar Dymarczyk, and Piotr Chomczyński, eds. 2014. Wojna, obraz, propaganda. Socjologiczna analiza plakatów wojennych [War, Image, Propaganda. The Sociological Analysis of War Posters]. Lodz: Wydawnictwo Uniwersytetu Łódzkiego.

Finkielsztein, Mariusz. 2017. "Nuda w środowisku uniwersyteckim [Boredom in the University Milieu]." Edukacja 1(140):108-120.

Finkielsztein, Mariusz. 2019. "Class-Related Academic Boredom among University Students: A Qualitative Research on Boredom Coping Strategies." Journal of Further and Higher Education 44(8):1098-1113.
Fiń, Anna. 2020. "An Ethnic Relations between Immigrant-Based Groups in the Light of Florian Znaniecki's Theory (Ethnic Relations as a Type of Social Relations: Case Study on Polish-Ukrainian Relations in Diaspora Situation)." Italian Sociological Review 10(2S):513-530.

Glaser, Barney. 1978. Theoretical Sensitivity: Advances in the Methodology of Grounded Theory. Mill Valley, CA: Sociology Press.

Glaser, Barney and Anselm L. Strauss. [1965] 2016. Awareness of Dying. Chicago: Aldine. Polish translation by Paweł Tomanek, Świadomość umierania. Cracow: Nomos.

Glaser, Barney and Anselm L. Strauss. [1967] 2009. Discovery of Grounded Theory: Strategies for Qualitative Research. Chicago: Aldine. Polish translation by Marek Gorzko, Odkrywanie Teorii Ugruntowanej. Strategie badania jakościowego. Cracow: Nomos.

Goffman, Erving. [1959] 1981. The Presentation of Self in Everyday Life. Garden City, NY: Doubleday. Polish translation by Helena Datner-Śpiewak and Paweł Śpiewak, Człowiek w teatrze życia codziennego. Warsaw: PIW.

Goffman, Erving. [1961] 2011. Asylums. Essay on the Social Situations of Mental Patients and Other Inmates. Garden City, NY: Anchor Books. Polish translation by Olena Waśkiewicz and Jacek Łaszcz, Instytucje totalne. Sopot: GWP.

Goffman, Erving. [1963] 2005. Stigma. Notes on the Management of Spoiled Identity. Englewood Cliffs, NJ: Prentice-Hall. Polish translation by Aleksandra Dzierżyńska and Joanna Tokarska-Bakir, Piętno. Rozważania o zranionej tożsamości. Gdansk: Gdańskie Wydawnictwo Psychologiczne.

Goffman, Erving. [1967] 2006. Interaction Ritual: Essays on Face to Face Behaviour. New York: Doubleday. Polish translation by Alina Sulżycka, Rytuat interakcyjny. Warsaw: PWN.

Goffman, Erving. 1975. “Charakterystyka instytucji totalnych [The Characteristics of Total Institutions, originally published in the Symposium on Preventive and Social Psychiatry, 1957]." Translated by Zbigniew Zwoliński. Pp. 150-178 in Elementy teorii socjologicznych. Materiały do dziejów współczesnej socjologii polskiej [The Elements of Sociological Theories. Materials for the History of Contemporary Polish Sociology], edited by W. Derczyński, A. Jasińska-Kania, and J. Szacki. Warsaw: PWN.

Gorzko, Marek. 2008. Procedury i emergencja. O metodologii klasycznych odmian teorii ugruntowanej [Procedures and Emergence. On the Methodology of Classical Varieties of Grounded Theory]. Szczecin: Wydawnictwo Uniwersytetu Szczecińskiego. 
Hałas, Elżbieta. 1983. "Florian Znaniecki - Ein verkannter Vorläufer des Symbolischen Interaktionismus." Zeitschrift für Soziologie 12(4):341-352.

Hałas, Elżbieta. 1986. "Florian Znaniecki - An Unrecognized Forerunner of Symbolic Interactionism." Pp. 75-90 in A Commemorative Book in Honor of Florian Znaniecki on the Centenary of His Birth, edited by Z. Dulczewski. Poznan: UAM.

Hałas, Elżbieta. 1987. Społeczny kontekst znaczeń w teorii symbolicznego interakcjonizmu [The Social Context of Meanings in the Theory of Symbolic Interactionism]. Lublin: Redakcja Wydawnictw Katolickiego Uniwersytetu Lubelskiego.

Hałas, Elżbieta. 1990. “Biografia a orientacja symbolicznego interakcjonizmu [Biography and the Orientation of Symbolic Interactionism]." Pp. 197-208 in Metoda biograficzna w socjologii [Biographical Method in Sociology], edited by J. Włodarek and M. Ziółkowski. Warsaw, Poznan: Państwowe Wydawnictwo Naukowe.

Hałas, Elżbieta. 1992. Konwersja. Perspektywa socjologiczna [Conversion: Sociological Perspective]. Lublin: Norbertinum.

Hałas, Elżbieta. 1994. Obywatelska socjologia szkoły chicagowskiej [The Civic Sociology of the Chicago School]. Lublin: Redakcja Wydawnictw Katolickiego Uniwersytetu Lubelskiego.

Hałas, Elżbieta. 2001. Symbole w interakcji [Symbols in Interactions].Warsaw: Oficyna Naukowa.

Hałas, Elżbieta and Krzysztof T. Konecki, eds. 2005. Konstruowanie jaźni i społeczeństwa. Europejskie warianty interakcjonizmu symbolicznego [Constructing the Self and Society. European Variants of Symbolic Interactionism]. Warsaw: Scholar.

Hernik, Kamila. 2007. “Doświadczenie konwersji przez studentów Wydziału Aktorskiego Akademii Teatralnej w Warszawie [Experience of Conversion by Students of the Actor's Department of the Theater Academy in Warsaw]." Przeglad Socjologii Jakościowej 3(3).

Hughes, Everett C. 1958. Men and Their Work. Glencoe, IL: Free Press.

Hughes, Everett C. 1997. “Careers." Qualitative Sociology 20(3):389-397.

Jakubczak, Franciszek. 1966. Konkursy na pamiętniki w Polsce, 1921-1966 [The Competitions of Life Records in Poland, 1921-1966]. Warsaw: Polska Akademia Nauk.
Jakubczak, Franciszek. 1989. “Zasoby pamiętników. Zasady i zakres ich użytkowania [Diaries Resources. Principles and Scope of Their Use]." Ruch Prawniczy, Ekonomiczny $i$ Socjologiczny 51(2):259-268.

Kacperczyk, Anna. 1998. “Budowanie interakcji z nieuleczalnie chorym [Building Interaction with the Terminally Ill Person]." Kultura i Społeczeństwo 42(2):182-200.

Kacperczyk, Anna. 1999. “Opieka nad pacjentem w stanie terminalnym [Caring for a Terminally Ill Patient]." Kultura i Społeczeństwo 43(2):103-128.

Kacperczyk, Anna. 2002. “Kultura organizacyjna zespołów opieki paliatywno-hospicyjnej [Organizational Culture of Palliative and Hospice Care Teams]." Przeglad Socjologiczny 51(2):145-185.

Kacperczyk, Anna. 2006. Wsparcie społeczne w instytucjach opieki paliatywnej i hospicyjnej [Social Support in Palliative and Hospice Care Institutions]. Lodz: Wydawnictwo Uniwersytetu Łódzkiego.

Kacperczyk, Anna. 2007a. “Badacz i jego poszukiwania w świetle Analizy Sytuacyjnej Adele E. Clarke [The Investigator and His/Her Explorations in Situational Analysis by Adele E. Clarke]." Przeglad Socjologii Jakościowej 3(2):5-32.

Kacperczyk, Anna. 2007b. “Recenzja książki Adele E. Clarke, Situational Analysis. Grounded Theory After Postmodern Turn, Thousand Oaks, CA: Sage 2005 [Review of the Book Adele E. Clarke, Situational Analysis. Grounded Theory After Postmodern Turn, Thousand Oaks, CA: Sage 2005]." Przeglad Socjologiczny 56(1):267-271.

Kacperczyk, Anna. 2012. “Badacz i jego ciało w procesie zbierania i analizowania danych - na przykładzie badań nad społecznym światem wspinaczki [The Researcher's Body in the Process of Data Gathering and Analysis-The Case of Ethnographic Study on the Social World of Climbing]." Przeglad Socjologii Jakościowej 8(2):32-63.

Kacperczyk, Anna. 2013. “Praca nad emocjami jako element aktywności górskiej i wspinaczkowej [Working on Emotions as a Part of Climbing and Mountaineering]." Przeglad Socjologii Jakościowej 9(2):70-103.

Kacperczyk, Anna. 2014. “Autoetnografia - technika, metoda, nowy paradygmat? O metodologicznym statusie autoetnografii [Autoethnography-Technique, Method, New Paradigm? On the Methodological Status of Autoethnography]." Przeglad Socjologii Jakościowej 10(3):32-74. 
Kacperczyk, Anna. 2016a. Społeczne światy. Teoria - empiria metody badań na przykładzie świata wspinaczki [Social Worlds. Theory-Empiricism-Research Methods on the Example of the World of Climbing]. Lodz: Wydawnictwo Uniwersytetu Łódzkiego.

Kacperczyk, Anna. 2016b. “'Nie muszę się tak bać!' Rola autoetnografii $\mathrm{w}$ analizie emocjonalnych aspektów działania wspinaczkowego ['I Don't Need to Be so Afraid!' The Role of Autoethnography in the Analysis of the Emotional Aspects of the Climbing Activity]." Pp. 215-253 in Auto/biograficzne aspekty praktyk poznawczych [Auto/Biographical Aspects of Cognitive Practices], edited by M. Kafar. Lodz: Wydawnictwo Uniwersytetu Łódzkiego.

Kacperczyk, Anna. 2017. “Rozum czy emocje? O odmianach autoetnografii, epistemologicznych pomostach i przepaściach między nimi [Reason or Emotions? On the Varieties of Autoethnography Epistemological Bridges and Gaps between Them]." Kultura i Społeczeństwo LXI(3):127-148.

Kaczmarczyk, Michał. 2018. “When Philosophy Met Social Psychology. An Interpretation of The Polish Peasant in Europe and America." European Journal of Sociology 59(2):257-299.

Kaczmarczyk, Michał. 2020. "The Concept of Values in Florian Znaniecki's Early Work." Italian Sociological Review 10(2S):425436.

Kaźmierska, Kaja. 1999. Doświadczenia wojenne Polaków a ksztattowanie tożsamości etnicznej. Analiza narracji kresowych [The War Experiences of Poles and the Formation of Ethnic Identity. The Analysis of Borderland Narratives]. Warsaw: IFiS PAN.

Kaźmierska, Kaja. 2004. “Wywiad narracyjny jako jedna $\mathrm{z}$ metod w badaniach biograficznych [Narrative Interview as a Method of Biographical Analysis]." Przeglad Socjologiczny 53(1):71-96.

Kaźmierska, Kaja. 2008. Biografia i pamięć. Na przykładzie pokoleniowego doświadczenia ocalonych z zagłady [Biography and Memory. On the Example of the Generational Experience of the Survivors of the Holocaust]. Cracow: Nomos.

Kaźmierska, Kaja, ed. 2012a. Metoda biograficzna w socjologii. Antologia tekstów [Biographical Method in Sociology. An Anthology of Texts]. Cracow: Nomos.

Kaźmierska, Kaja. 2012b. Biography and Memory: The Generational Experience of the Shoah Survivors. Boston: Academic Studies Press.
Kaźmierska, Kaja, Andrzej Piotrowski, and Katarzyna Waniek. 2012. "Transnational Work in the Biographical Experiences of Traditional Professions and Corporate Executives: Analysis of Two Cases." Pp. 76-101 in The Evolution of European Identities, edited by R. Miller and G. Day. Houndmills: Palgrave Macmillan.

Konecki, Krzysztof T. 1987. "Redefinitions Of Self in Concentrations Camps." Pp. 27-35 in Approaches To The Study Of FaceTo-Face Interaction, edited by Z. Bokszański and M. Czyżewski Folia Sociologica 13. Lodz: Wydawnictwo Uniwersytetu Łódzkiego.

Konecki, Krzysztof T. 1989. "The Methodology of Grounded Theory in the Research of the Situation of Work." The Polish Sociological Bulletin 2:59-74.

Konecki, Krzysztof T. 1994. Kultura organizacyjna japońskich przedsiębiorstw. Studium socjologiczne [The Organizational Culture of Japanese Enterprises. Sociological Study]. Lodz: Wydawnictwo Uniwersytetu Łódzkiego.

Konecki, Krzysztof T. 1997. "Time in the Recruiting Search Process by Headhunting Companies." Pp. 131-146 in Grounded Theory in Practice, edited by A. Strauss and J. Corbin. Thousand Oaks, CA: Sage.

Konecki, Krzysztof T. 1999. “The Moral Aspects of Headhunting. The Analysis of Work by Executive Search Companies in 'Competition Valley.'” Polish Sociological Review 4(128):553-568.

Konecki, Krzysztof T. 2000. Studia z metodologii badań jakościowych. Teoria ugruntowana [Studies in the Methodology of Qualitative Research. Grounded Theory]. Warsaw: PWN.

Konecki, Krzysztof T. 2005a. "The Problem of Symbolic Interaction and of Constructing Self." Qualitative Sociology Review 1(1):68-89.

Konecki, Krzysztof T. 2005b. Ludzie i ich zwierzęta. Interakcjonistyczno-symboliczna analiza społecznego świata właścicieli zwierząt domowych [People and Their Animals. Symbolic Interactionist Analysis of the Social World of Pet Owners]. Warsaw: Scholar.

Konecki, Krzysztof T. 2005c. “Wizualne wyobrażenia. Główne strategie badawcze w socjologii wizualnej a metodologia teorii ugruntowanej [Visual Images. Main Research Strategies in the Visual Sociology and the Methodology of Grounded Theory]." Przeglad Socjologii Jakościowej 1(1):42-63.

Konecki, Krzysztof T. 2007. “Nowi pracownicy a kultura organizacyjna przedsiębiorstwa. Studium folkloru fabrycznego [New 
Employees and the Company's Organizational Culture. The Study of Factory Folklore]." Przegląd Socjologii Jakościowej 3(1).

Konecki, Krzysztof T. 2008a. „Touching and Gesture Exchange as an Element of Emotional Bond Construction. Application of Visual Sociology in the Research on Interaction between Humans and Animals." Forum Qualitative Sozialforschung / Forum: Qualitative Social Research 9(3): Art. 33.

Konecki, Krzysztof T. 2008b. “Economic Sociology as a Sociology of Economic Action." In Management: Qualitative and Quantitative Research, edited by A. Nowak and B. Glinka. Warsaw: Wydawnictwo Naukowe Wydziału Zarządzania Uniwersytetu Warszawskiego.

Konecki, Krzysztof T. 2010. “Procesy tożsamościowe a dialogiczność jaźni - problem anamnezis [Identity Processes and Dialogicality of the Self. Problem of Anamnesis]." Pp. 331339 in Procesy tożsamościowe. Symboliczno-interakcyjny wymiar konstruowania ładu i nieładu społecznego [Identity Processes. The Symbolic-Interactionist Dimension of Constructing Social Order and Disorder], edited by K. T. Konecki and A. Kacperczyk. Lodz: Wydawnictwo Uniwersytetu Łódzkiego.

Konecki, Krzysztof T. 2011. "Visual Grounded Theory: A Methodological Outline and Examples from Empirical Work." Revija za Sociologiju 41(2):131-160.

Konecki, Krzysztof T. 2012. “Wizualna teoria ugruntowana. Podstawowe zasady i procedury [Visual Grounded Theory. Basic Rules and Procedures]." Przegląd Socjologii Jakościowej $8(1): 12-45$.

Konecki, Krzysztof T. 2014. "Socjologia emocji według Thomasa Scheffa [The Sociology of Emotions by Thomas Scheff]." Pp. 11-38 in Emocje w życiu codziennym. Analiza kulturowych, społecznych i organizacyjnych uwarunkowań ujawniania i kierowania emocjami [Emotions in Everyday Life. The Analysis of Cultural, Social, and Organizational Determinants of Revealing and Managing Emotions], edited by K. T. Konecki and B. Pawłowska. Lodz: Wydawnictwo Uniwersytetu Łódzkiego.

Konecki, Krzysztof T. 2015. Is the Body the Temple of the Soul? Modern Yoga Practice as a Psychosocial Phenomenon. Lodz: Wydawnictwo Uniwersytetu Łódzkiego / Cracow: Jagiellonian University Press.

Konecki, Krzysztof T. 2017. “Qualitative Sociology.” Pp. 143-152 in The Cambridge Handbook of Sociology. Core Areas in Sociology and the Development of the Discipline, Vol. 1, edited by K. O. Korgen. Cambridge: Cambridge University Press.
Konecki, Krzysztof T. 2018. Advances in Contemplative Social Research. Lodz: Wydawnictwo Uniwersytetu Łódzkiego / Cracow: Jagiellonian University Press.

Konecki, Krzysztof T. and Piotr Chomczyński. 2012. Stownik Socjologii Jakościowej [The Dictionary of Qualitative Sociology]. Warsaw: Difin.

Konecki, Krzysztof T., Anna Kacperczyk, and Łukasz T. Marciniak. 2005. "Polish Qualitative Sociology: The General Features and Development." Forum Qualitative Sozialforschung / Forum: Qualitative Social Research 6(3): Art. 27.

Kowalczyk, Beata. 2014. “(Nie)przekładalność (?) perspektyw w świecie muzyki klasycznej. Autoetnografia socjologa-obserwatora i japonisty-tłumacza [Reciprocity (?) of Perspectives in the World of Classical Music. Autoethnography of Sociologist-Observer and Japanese Language Translator]." Przeglad Socjologii Jakościowej 10(3):202-221.

Kowalczyk, Beata. in press. Transnational Musicians. Precariousness, Ethnicity and Gender in the Creative Industry. Abingdon-on-Thames: Routlege.

Krzemiński, Ireneusz. 1986. Symboliczny interakcjonizm i socjologia [Symbolic Interactionism and Sociology]. Warsaw: Państwowe Wydawnictwo Naukowe.

Krzemiński, Ireneusz. 1997. Solidarność - projekt polskiej demokracji [Solidarity-A Project of Polish Democracy]. Warsaw: Oficyna Naukowa.

Krzemiński, Ireneusz. 2013. Solidarność. Niespetniony projekt polskiej demokracji [Solidarity. The Unfulfilled Project of Polish Democracy]. Gdansk: Europejskie Centrum Solidarności.

Krzemiński, Ireneusz. 2016. Solidarność - doświadczenie i pamięć po raz drugi [Solidarity-Experience and Memory for the Second Time]. Gdansk: Europejskie Centrum Solidarności.

Kubczak, Anna. 2011. “Proces adaptacji użytkownika do środowiska online [The Process of Adapting the User to the Online Environment]." Przeglad Socjologii Jakościowej 7(3):57-84.

Lesiak, Michał. 2019. Brudna praca w zawodach medycznych. Konteksty interakcji pacjent-personel medyczny $w$ procesie leczenia [Dirty Work in Medical Professions. Contexts of Patient-Medical Staff Interaction in the Treatment Process]. Lodz: Wydawnictwo UŁ.

Łapiński, Zdzisław. 1977. "Frame Analysis. Uwagi końcowe [Frame Analysis. The End Notes].” Teksty 5-6:229-258. 
Manterys, Alesander. 2000. Klasyczna idea definicji sytuacji [The Classic Idea of Defining a Situation]. Warsaw: WUW.

Manterys, Alesander. 2008. Sytuacje społeczne [Social Situations]. Cracow: Nomos.

Marciniak, Łukasz T. 2008. “Stawanie się nauczycielem akademickim. Analiza symboliczno-interakcjonistyczna [Becoming an Academic Teacher. Symbolic Interactionist Analysis]." Przegląd Socjologii Jakościowej 4(2).

Marciniak, Łukasz T. 2016. Bazary. Kooperacja czy konkurencja? [Bazaars: Cooperation Or Competition?]. Lodz: Wydawnictwo UŁ.

Mead, George, H. [1932] 1975. Mind Self and Society from the Standpoint of a Social Behaviorist. Chicago: University of Chicago Press. Polish translation by Zofia Zwolińska, Umyst, osobowość i społeczeństwo. Warsaw: PWN.

Miller, Piotr. 2010. “Konstruowanie tożsamości ratownika górskiego [Constructing the Mountain Rescuer's Identity]." Przegląd Socjologii Jakościowej 6(1).

Mróz, Ewa. 2012. Oczami fanów Michaela Jacksona [Through the Eyes of Michael Jackson's Fans]. Gdynia: Novae Res.

Mucha, Janusz. 1992. Cooley. Warsaw: Wiedza Powszechna.

Niedbalski, Jakub. 2015. Living and Working in a Social Welfare Home in Poland. A Sociological Study on the Interaction of Personnel with Mentally Handicapped Charges. Lodz: Wydawnictwo UŁ.

Niedbalski, Jakub. 2016a. “'Wychodzenie z cienia' - analiza procesu ujawnienia i samoakceptacji własnej niepełnosprawności przez sport ['Coming Out of the Shadows'-The Analysis of the Process of Disclosure and Self-Acceptance of Own Disability through Sport]." Kultura i Społeczeństwo 3:13-34.

Niedbalski, Jakub. 2016b. "Dylematy etyczne i problemy metodologiczne warsztatu badacza - rozważania na przykładzie badań prowadzonych w środowisku osób z niepełnosprawnością intelektualną oraz niepełnosprawnością fizyczną [Ethical Dilemmas and Methodological Problems of the Researcher's Skills-Considerations Based on the Example of Research Conducted in the Environment of People with Intellectual and Physical Disabilities]." Studia Humanistyczne AGH 15(4):37-53.

Niedbalski, Jakub. 2016c. “Career Patterns of Disabled Sportsmen-An Analysis of the Phenomenon from the Perspective of Symbolic Interactionism." Człowiek Niepetnosprawność Społeczeństwo 3(33):19-35.
Niedbalski, Jakub. 2016d. "The Educational Role of Sport Practiced by People with Disabilities." International Journal of Psycho-Educational Sciences (IJPES) 5(2):101-110.

Niedbalski, Jakub. 2017. Wymiary, konteksty I wzory karier. Proces stawania się sportowcem przez osobę z niepetnosprawnościa fizyczna - analiza społecznych mechanizmów (re)konstruowania tożsamości [Career Dimensions, Contexts, and Patterns. The Process of Becoming an Athlete by a Person with a Physical Disability - The Analysis of Social Mechanisms of (Re)Construction of Identity]. Lodz: Wydawnictwo Uniwersytetu Łódzkiego.

Niedbalski, Jakub. 2019. Niepetnosprawność i osoby z niepetnosprawnościa. Od pasywności i wykluczenia do aktywności życiowej i integracji społecznej [Disability and People with Disabilities. From Passivity and Exclusion to Life Activity and Social Integration]. Lodz: Wydawnictwo Uniwersytetu Łódzkiego.

Niedbalski, Jakub and Izabela Ślęzak. 2016. “Dylematy etyczne i problemy metodologiczne w kontekście upowszechniania i archiwizacji danych jakościowych [Ethical Dilemmas and Methodological Problems in the Context of Dissemination and Archiving of Qualitative Data]." Rocznik Nauk Społecznych 8(44):223-241.

Park, Robert E. and Ernest Burgess. 1921. Introduction to the Science of Sociology. Chicago: University of Chicago Press.

Pawłowska, Beata. 2012. “Duma i wstyd jako emocje kierujące zachowaniem. Problemy metodologiczne [Pride and Shame as Emotions Driving Behavior. Methodological Problems]." Societas/Communitas 2(14):39-54.

Pawłowska, Beata. 2014. “Emocje społeczne w teorii Theodore’a Kempera [Social Emotions in Theodore Kemper's Theory]." Pp. 39-52 in Emocje w życiu codziennym. Analiza kulturowych, społecznych $i$ organizacyjnych uwarunkowań ujawniania $i$ kierowania emocjami [Emotions in Everyday Life. The Analysis of Cultural, Social, and Organizational Determinants of Revealing and Managing Emotions], edited by K. T. Konecki and B. Pawłowska. Lodz: Wydawnictwo Uniwersytetu Łódzkiego.

Pawłowska, Beata and Piotr Chomczyński. 2012. "Sposoby radzenia sobie $z$ emocjami negatywnymi na przykładzie grupy nauczycieli [The Ways of Dealing with Negative Emotions on the Example of a Group of Teachers]." Studia Edukacyjne 21:141-162.

Pawłowska, Beata and Krzysztof T. Konecki. 2013. “W stronę socjologii emocji. Wstęp do numeru [Towards the Sociology of Emotions. Introduction to the Issue]." Przeglad Socjologii Jakościowej 9(2):6-9. 
Pawłowska, Beata and Krzysztof T. Konecki, eds. 2014. Emocje $w \dot{z} y c i u$ codziennym. Analiza kulturowych, społecznych i organizacyjnych uwarunkowań ujawniania i kierowania emocjami [Emotions in Everyday Life. The Analysis of Cultural, Social, and Organizational Conditions for the Disclosure and Management of Emotions]. Lodz: Wydawnictwo Uniwersytetu Łódzkiego.

Piotrowski, Andrzej. 1985. "Pojęcie tożsamości w tradycji interakcjonizmu symbolicznego [The Concept of Identity in the Tradition of Symbolic Interactionism]." Kultura i Społeczeństwo 29(3):53-73.

Piotrowski, Andrzej. 1986. “Socjolingwistyka a socjologia. Jakościowe i ilościowe podejście do teorii zależności między językiem a społeczeństwem [Sociolinguistics and Sociology. The Qualitative and Quantitative Approach to the Theory of the Relationship between Language and Society]." Kultura i Społeczeństwo 3:61-81.

Piotrowski, Andrzej. 1998. Ład Interakcji. Studia z socjologii interpretatywnej [Orderliness of Interaction. Studies in the Interpretive Sociology]. Lodz: Wydawnictwo Uniwersytetu Łódzkiego.

Prus, Robert. 1996. Symbolic Interaction and Ethnographic Research: Intersubjectivity and the Study of Human Lived Experience. Albany, NY: State University of New York Press.

Prus, Robert. 1997. Subcultural Mosaics and Intersubjective Realities. An Ethnographic Research Agenda for Pragmatizing the Social Sciences. Albany, NY: State University of New York Press.

Prus, Robert. 2007. “Picie jako działanie. Analiza interakcjonistyczna [Drinking as Activity. An Interactionist Perspective, originally published in the Journal of Studies on Alcohol, 1983]." Translated by Dominika Byczkowska. Przeglad Socjologii Jakościowej 3(2):112-125.

Prus, Robert. 2011. “Twórczość poetycka i społecznie ustanawiana rzeczywistość. Platońskie i Arystotelejskie ujęcie motywów pragmatycznych w greckiej literaturze pięknej [Poetic Expression and Human Enacted Realities: Plato and Aristotle Engage Pragmatist Motifs in Greek Fictional Representations, originally published in the Qualitative Sociology Review, 2009]. Translated by Waldemar Dymarczyk and Karolina Kubicka. Przeglad Socjologii Jakościowej 7(2)111-138.

Prus, Robert. 2013a. “Representing, Defending, and Questioning Religion: Pragmatist Sociological Motifs in Plato's Timaeus, Phaedo, Republic, and Laws." Qualitative Sociology Review 9(1):6-42.
Prus, Robert. 2013b. “Generating, Intensifying, and Redirecting Emotionality: Conceptual and Ethnographic Implications of Aristotle's Rhetoric." Qualitative Sociology Review 9(4):6-42.

Prus, Robert and Scott Grills. 2003. The Deviant Mystique: Involvements, Realities, and Regulation. Westport, CT: Praeger.

Pyfel, Łukasz. 2015. “Badacz jakościowy w świątyni liczb i pieniądza - wykorzystanie metod jakościowych w badaniu rynków finansowych [Qualitative Researcher in the Temple of Numbers and Money-The Use of Qualitative Methods in Researching Financial Markets]." Przeglad Socjologii Jakościowej 11(1):70-83.

Rokuszewska-Pawełek, Alicja. 2002. Chaos i przymus. Trajektorie wojenne Polaków - analiza biograficzna [Chaos and Constraint. War Trajectories of Poles-Biographical Analysis]. Lodz: Wydawnictwo Uniwersytetu Łódzkiego.

Schatzman, Leonard and Anselm L. Strauss. 1973. Field Research. Englewood Cliffs, NJ: Prentice Hall.

Schütze, Fritz. 1983. "Biographieforschung und Narratives Interview." Neue Praxis 13(3):283-293.

Sinatti, Giulia. 2008. "The Polish Peasant Revisited. Thomas and Znaniecki's Classic in the Light of Contemporary Transnational Migration Theory." Sociologica 2:1-22.

Słowińska, Karolina. 2010. "Społeczny świat hodowców gołębi pocztowych [The Social World of Racing Pigeon Breeders]." Przegląd Socjologii Jakościowej 6(3).

Stanley, Liz. 2010. "To the Letter: Thomas and Znaniecki's The Polish Peasant and Writing a Life, Sociologically." Life Writing 7(2):139-151.

Strauss, Anselm L. [1959] 2013. Mirrors and Masks. Glencoe, IL: Free Press. Polish translation by Agnieszka Hałas, Zwierciadta i Maski. W poszukiwaniu tożsamości. Cracow: Nomos.

Strauss, Anselm L. 1987. Qualitative Analysis for Social Scientists. Cambridge: Cambridge University Press.

Strauss, Anselm L. 1993. Continual Permutations of Action. New York: Aldine.

Szacki, Jerzy. 2005. Historia myśli socjologicznej [The History of Sociological Thought]. Warsaw: PWN.

Szczepański, Jan. 1976. “Chłop Polski w Europie i w Ameryce [The Polish Peasant in Europe and America]." Przeglad Socjologiczny 28:167-177. 
Sztompka, Piotr. 2005. Socjologia wizualna. Fotografia jako metoda badawcza [Visual Sociology. Photography as the Research Method]. Warsaw: PWN.

Ślęzak, Izabela. 2009. "Stawanie się poetą. Analiza interakcjonistyczno-symboliczna [Becoming a Poet. Symbolic Interactionist Analysis]." Przeglad Socjologii Jakościowej 5(1).

Ślęzak, Izabela. 2015. “The Influence of Significant Others on the Course of the Process of Leaving Sex Work." Przeglad Socjologii Jakościowej 11(3):132-153.

Ślęzak, Izabela. 2017. “Violence Towards Sex Workers. Analysis Based on Research into the Field of Indoor Sex Work in Poland." Polish Sociological Review 2(198):237-254.

Thomas, William I. and Florian Znaniecki. [1918-1920] 1958. The Polish Peasant in Europe and America. New York: Dover Publications. Polish translations: 1976. Chłop polski w Europie i w Ameryce. Tom I. Organizacja grupy pierwotnej, translated by Maryla Metelska; Tom II. Organizacja grupy pierwotnej, translatd by Endla Oengo-Knoche; Tom III. Pamiętnik imigranta, translated by Stanisław Helsztyński; Tom IV. Dezorganizacja i reorganizacja $w$ Polsce, translated by Irena Wyrzykowska; Tom V. Organizacja i dezorganizacja w Ameryce, translated by Anna Bartkowicz. Warsaw: Ludowa Spółdzielnia Wydawnicza.

Tittenbrun, Jacek. 1983. Interakcjonizm we współczesnej socjologii amerykańskiej [Interactionism in Contemporary American Sociolo$g y$ ]. Poznan: Wydawnictwo Naukowe UAM.

Wagner, Izabela. 2005. “Sprzężenie karier. Konstrukcja karier w środowiskach artystycznych i intelektualnych [Career Coupling. The Construction of Careers in Artistic and Intellectual Circles]." Przegląd Socjologii Jakościowej 1(1):20-41.

Wagner, Izabela. 2011. Becoming Transnational Professional. Kariery $i$ mobilność polskich elit naukowych [Becoming Transnational Professional. Mobility and Careers of the Polish Scientific Elite]. Warsaw: Scholar.

Wagner, Izabela. 2015. Producing Excellence: The Making of Virtuosos. New Brunswick, NY: Rutgers University Press.

Wagner, Izabela. 2016. “Discovering the Secret of Excellence: Everett Hughes as a Source of Inspiration in Researching Creative Careers." Pp. 193-210 in The Anthem Companion to Everett Hughes, edited by M. Santoro and R. Helmes-Hayes. London: Anthem Editions.

Wagner, Izabela. 2020. Bauman: A Biography. Cambridge, Medford: Polity Press.
Węgleński, Jan. 1983. Urbanizacja. Kontrowersje wokót pojęcia [Urbanization. Controversy around the Concept]. Warsaw: Wydawnictwo PWN.

Węgleński, Jan. 1988. Metropolitalna Ameryka [Metropolitan America]. Warsaw: Wiedza Powszechna.

Wilson, Thomas P. 1970. "Normative and Interpretive Paradigms in Sociology." Pp. 57-79 in Understanding Everyday Life: Toward the Reconstruction of Sociological Knowledge, edited by J. D. Douglas. Chicago: Aldine Publishing.

Wincławski, Włodzimierz. 2012. “Wstęp do socjologii Floriana Znanieckiego - wyzwanie rzucone polskiej socjologii i jego następstwa (dziewięćdziesiąta rocznica publikacji dzieła) [Introduction to Florian Znaniecki's Sociology-The Challenge to Polish Sociology and Its Consequences (90th Anniversary of the Publication of the Work)]." Roczniki Historii Socjologii 2:5-18.

Włodarek, Jan and Marek Ziółkowski, eds. 1990. Metoda biograficzna w socjologii [Biographical Method in Sociology]. Warsaw: PWN.

Wojciechowska, Magdalena. 2012. Agencja towarzyska - (nie) zwykłe miejsce pracy [The Escort Agency-An (Extra)Ordinary Workplace]. Cracow: Nomos.

Wojciechowska, Magdalena. 2015. “Men Who Like Using and Abusing Women: The Perspective of Clients on Escort Agency Workers." Studies in Symbolic Interaction 45:1-21.

Wojciechowska, Magdalena. 2020. Dwie matki jednego dziecka [Two Mothers of One Child]. Lodz: Wydawnictwo Uniwersytetu Łódzkiego.

Woroniecka, Grażyna. [1998] 2003. Interakcja symboliczna a hermeneutyczna kategoria przed-rozumienia [Symbolic Interaction and the Hermeneutical Category of Pre-Comprehension]. Warsaw: Oficyna Naukowa.

Wyka, Anna. 1988. “Qualitative Sociology in Poland." Qualitative Sociology 11(1\&2):63-76.

Wyka, Anna. 1993. Badacz społeczny wobec doświadczenia [Social Researcher in the Face of Experience]. Warsaw: Wydawnictwo IFiS PAN.

Zakrzewska-Manterys, Elżbieta. 1996. “Odteoretycznienie świata społecznego. Podstawowe pojęcia teorii ugruntowanej [De-Theorizing of Social World. Basics of Grounded Theory]." Studia Socjologiczne 1:5-26. 
Ziółkowski, Marek. 1981. Znaczenie, interakcja, rozumienie [Meaning, Interaction, Understanding]. Warsaw: PWN.

Znaniecki, Florian. 1919. Cultural Reality. Chicago: University of Chicago Press.

Znaniecki, Florian. 1922. Wstęp do Socjologii [Introduction to Sociology]. Poznan: Gebethner \& Wolf.

Znaniecki, Florian. 1925. The Laws of Social Psychology. Warsaw, Cracow, Poznan: Gebethner \& Wolf.

Znaniecki, Florian. 1928. Socjologia wychowania, t. I [Sociology of Education, Vol. I]. Warsaw: Komisja Pedagogiczna MWRiOP.

Znaniecki, Florian. 1930. Socjologia wychowania, t. II [Sociology of Education, Vol. II]. Warsaw: Komisja Pedagogiczna MWRiOP.

Znaniecki, Florian. 1932. Miasto w świadomości jego obywateli [The City in View of Its Inhabitants]. Poznan: Polski Instytut Socjologiczny.
Znaniecki, Florian. 1934. The Method of Sociology. New York: Farrar and Rinehart.

Znaniecki, Florian. 1936. Social Actions. New York: Farrar \& Reinhart.

Znaniecki, Florian. [1938] 1984. "Przedmowa [Preface]." In Młode pokolenie chłopów. Tom I [The Young Generation of Peasants. Vol. I]. Warsaw: Ludowa Spółdzielnia Wydawnicza.

Znaniecki, Florian. 1940. The Social Role of the Man of Knowledge. New York: Columbia University Press.

Znaniecki, Florian. 1952. Cultural Sciences. Their Origin Development. Urbana, IL: University of Illinois Press.

Znaniecki, Florian. 1965. Social Relations and Social Roles. San Francisco: Chandler Publishing Company.

Znaniecki, Florian. 1976. “Autobiografia jako materiał do badań socjologicznych [Autobiography as a Material for Sociological Research]." Przeglad Socjologiczny 28 154-167.

\section{Citation}

Konecki, Krzysztof T. and Anna Kacperczyk. 2020. “Symbolic Interactionism in Poland. Inspirations and Development." Qualitative Sociology Review 16(4):8-34. Retrieved Month, Year (http://www.qualitativesociologyreview.org/ENG/archive_eng.php). DOI: http://dx.doi.org/10.18778/1733-8077.16.4.02 